\title{
A DESCRIPTIVE COMPARATIVE STUDY OF VULVOVAGINAL COMPLAINTS IN WOMEN WITH DIABETIC HUSBANDS AND WITH WOMEN WHOSE HUSBANDS HAVE NO DIABETES
}

\author{
Sandhya Dixit' ${ }^{1}$ Saroja Adapa ${ }^{2}$, Gayathri Dixit ${ }^{3}$ \\ ${ }^{1}$ Assistant Professor, Department of Obstetrics and Gynaecology, Government Maternity Hospital, Sultan Bazar, Osmania Medical \\ College, Hyderabad. \\ ${ }^{2}$ Assistant Professor, Department of Obstetrics and Gynaecology, Government Maternity Hospital, Sultan Bazar, Osmania Medical \\ College, Hyderabad. \\ ${ }^{3}$ Medical Officer, Primary Health Centre, Rangareddy District, Hyderabad.
}

\section{ABSTRACT}

\section{BACKGROUND}

The term leucorrhoea is restricted to those conditions when normal vaginal secretion is increased in amount without increase of leucocytes. Purulent discharge is due to specific infections such as gonorrhoea, trichomoniasis, moniliasis and ulcerated growths of cervix and vagina. The white discharge may be physiological or pathological. This physiological white discharge occurs at puberty, ovulation, premenstrual period and pregnancy. During puberty and pregnancy, the increase in secretion is due to increase in vascularity and it is of temporary duration, does not need treatment.

\section{MATERIALS AND METHODS}

This descriptive comparative study was done at Government Maternity Hospital, Sultan Bazar, Department of OBG, Osmania Medical College, Hyderabad, Telangana, from January 2014 to December 2015. Women with a complaint of white discharge were selected and their husband's glycaemic status was evaluated by taking detailed history and screening for diabetes by OGTT. Those men who were known diabetics already on treatment and those who were diagnosed in the screening were included in the study group of women with diabetic spouses. Women with white discharge and whose husbands were not diabetic were included in the control group. Each group consisted of 50 patients. Variables like age, socioeconomic status, symptoms, nature of discharge, response to treatment, Pap smear and recurrence rate were compared between the two groups.

\section{RESULTS}

Women whose spouses had diabetes had specific vaginitis at a later age and belonged to higher socioeconomic status when compared with control group. In Pap smear also, the degree of inflammation is more in women with diabetic husbands. There is a statistically significant delay in response to treatment and increased recurrence rate in the study group.

\section{CONCLUSION}

Diagnosis of diabetes in the spouses of women with white discharge is important to know the nature of symptoms, to administer effective treatment and to prevent recurrence.

\section{KEYWORDS}

White Discharge, Diabetes, Pap Smear, Inflammation, Spousal Diabetes.

HOW TO CITE THIS ARTICLE: Dixit S, Adapa S, Dixit G. A descriptive comparative study of vulvovaginal complaints in women with diabetic husbands and with women whose husbands have no diabetes. J. Evolution Med. Dent. Sci. 2017;6(86):5934-5936, DOI: $10.14260 /$ jemds/2017/1291

\section{BACKGROUND}

The term leucorrhoea is restricted to those conditions when normal vaginal secretion is increased in amount without increase of leucocytes. Purulent discharge is due to specific infections such as gonorrhoea, trichomoniasis, moniliasis and ulcerated growths of cervix and vagina. The white discharge may be physiological or pathological. This physiological white discharge occurs at puberty, ovulation, premenstrual period and pregnancy. During puberty and pregnancy the increase in secretion is due to increase in vascularity and it is of temporary duration, does not need treatment.

The white discharge containing leucocytes and causative organisms is due to specific vaginal infection. ${ }^{1-3}$

'Financial or Other Competing Interest': None.

Submission 18-05-2017, Peer Review 11-10-2017,

Acceptance 19-10-2017, Published 26-10-2017.

Corresponding Author:

Dr. Sandhya Dixit,

Plot No. 130, Sriramnagar Colony,

Vanasthalipuram, Hyderabad-500070,

Telangana State.

E-mail: sandhyadixit9@yahoo.com

DOI: $10.14260 /$ jemds $/ 2017 / 1291$
The white discharge can cause itching, vaginitis, dysuria, dyspareunia and foul-smelling discharge. The ascent of infection from vagina to upper genital tract may lead to hydrosalpinx, pyosalpinx and tubo-ovarian mass. Pelvic Inflammatory Disease (PID) can cause adhesions leading to infertility and ectopic pregnancies. So early identification and treatment of white discharge can prevent these complications. A detailed history regarding predisposing factors like steroid and antibiotic intake, HIV, diabetes mellitus in the patient is useful for early diagnosis and prevention of complications. Diabetes in males predisposes to candida, gonococcal infection, HIV and HPV. ${ }^{2}$ These infections can cause balanoposthitis and they can be transmitted to their spouses. These infections in females can cause metaplasia of cervical epithelium. Persistence of metaplasia can cause CIN (cervical intraepithelial neoplasia). Screening of women whose husbands are diabetics with Pap smear is helpful in early identification of CIN. ${ }^{1}$

So in the present study, we studied the association of severity of white discharge and abnormal Pap smears with spousal diabetes by comparing women whose husbands are with and without diabetes mellitus. 


\section{MATERIALS AND METHODS}

This descriptive comparative study was done at Government Maternity Hospital, Sultan Bazar, Department of OBG, Osmania Medical College, Hyderabad, Telangana, from January 2014 to December 2015. After informed consent, a consecutive sample of fifty women with complaints of vulvovaginal complaints, whose husbands are suffering from Diabetes Mellitus are selected after confirmation of diabetes with Oral Glucose Tolerance Test (OGTT) and compared with fifty women with similar complaints, but whose husbands are not diabetic. The spouses of women with white discharge are evaluated with OGTT. Those with two values being abnormal were considered as diabetic and included in the Diabetic spouses group and those with normal OGTT values were considered as non-diabetic and included in the control group. All women are subjected to thorough history taking, general examination, vital data, per speculum and bimanual examination. Baseline tests were done- $\mathrm{Hb} \%$, Complete Blood Picture (CBP), Erythrocyte Sedimentation Rate (ESR), Random Blood Sugar (RBS), Thyroxine Stimulating Hormone (TSH), Complete Urine Examination (CUE) and Urine Culture/ Sensitivity (C/S). Papanicolaou (Pap) smear was taken from all of them. Ultrasound scanning for pelvic organs was done for all of them. Treatment was by syndromic approach and consisted of oral Metronidazole, fluoroquinolones, aminoglycosides and supportive treatment. Wherever Urine $\mathrm{C} / \mathrm{S}$ was positive, appropriate and suitable antibiotic was selected. Monitoring of treatment was done meticulously with strict one-week and four-week followup in the clinic or hospital with physical examination. Later both the groups were followed up for 2 years telephonically or advised physical exam if having any complaints. Women with any recurrence of symptoms in both groups were advised to report immediately. A second antibiotic was added wherever necessary during followup, either for persistence of symptoms or based on C/S reports. Spouse evaluation and status of diabetes mellitus was noted. Thorough couple counselling was done. The variables studied in both groups were age at first visit, nature of complaints, socioeconomic groups, investigations done, time taken for relief of symptoms and recurrence of symptoms during followup.

\section{Exclusion Criteria}

All pregnant women, unmarried women, women suffering with Diabetes Mellitus.

\section{Inclusion Criteria}

All married, non-pregnant women with relevant complaints after excluding the above criteria.

\section{Statistical Analysis}

Proportions were used to describe the categorical variables and to compare them between the study and control groups. Chi-square test was used to test the hypothesis where there was difference in proportions between the two groups. Yates' continuity correction was used where necessary. The data was entered in Microsoft Excel and was analysed using $\mathrm{R}$ version 3.2.3. ${ }^{4}$

\section{RESULTS}

\begin{tabular}{|c|c|c|c|}
\hline \multirow{2}{*}{$\begin{array}{l}\text { Sl. } \\
\text { No. }\end{array}$} & \multirow{2}{*}{$\begin{array}{l}\text { Age Group } \\
\text { (In Years) }\end{array}$} & $\begin{array}{c}\text { Women with Diabetic } \\
\text { Spouses Group }\end{array}$ & $\begin{array}{c}\text { Women in } \\
\text { Control Group }\end{array}$ \\
\hline & & n (\%) & n (\%) \\
\hline 1 & $<20$ & $2(4)$ & 9 (18) \\
\hline 2 & $21-25$ & $2(4)$ & $18(36)$ \\
\hline 3 & $26-30$ & $21(42)$ & $14(28)$ \\
\hline 4 & $31-35$ & $16(32)$ & $5(10)$ \\
\hline 5 & $>35$ & $9(18)$ & $4(8)$ \\
\hline & Total & $50(100)$ & $50(100)$ \\
\hline \multicolumn{4}{|c|}{ Chi-square $=26.34 ; \mathrm{df}=4 ; \mathrm{p}<0.001$} \\
\hline & $\begin{array}{l}\text { Table } \\
\text { in th }\end{array}$ & $\begin{array}{l}\text { Age Distribution of } \\
\text { tudy and Control Gr }\end{array}$ & $\begin{array}{l}\text { men } \\
\text { ips }\end{array}$ \\
\hline
\end{tabular}

More than $2 / 3^{\text {rd }}$ women with diabetic spouses are in the age group of 26 to 35 years when compared to women in control group in whom the majority age group is 21 to 30 years.

\begin{tabular}{|c|c|c|c|c|}
\hline $\begin{array}{l}\text { Sl. } \\
\text { No. }\end{array}$ & $\begin{array}{c}\text { Nature of } \\
\text { Complaints }\end{array}$ & $\begin{array}{c}\text { Women with } \\
\text { Diabetic } \\
\text { Spouses Group }\end{array}$ & $\begin{array}{c}\text { Women in } \\
\text { Control } \\
\text { Group }\end{array}$ & P Value* \\
\hline & & n (\%) & n (\%) & \\
\hline 1 & Pelvic Pain & $18(36)$ & $17(34)$ & $p>0.05$ \\
\hline 2 & $\begin{array}{c}\text { Copious White } \\
\text { Discharge } \\
\text { Staining } \\
\text { Clothes } \\
\end{array}$ & $13(26)$ & $6(12)$ & $p>0.05$ \\
\hline 3 & $\begin{array}{c}\text { Offensive } \\
\text { Odour }\end{array}$ & $16(32)$ & $11(22)$ & $p>0.05$ \\
\hline 4 & Pruritus & $31(62)$ & $10(20)$ & $\mathrm{p}<0.001$ \\
\hline 5 & $\begin{array}{l}\text { Micturition } \\
\text { Complaints }\end{array}$ & $19(38)$ & $13(26)$ & $p>0.05$ \\
\hline 6 & $\begin{array}{c}\text { Type of White } \\
\text { Discharge } \\
\text { Curdy/ } \\
\text { Purulent } \\
\end{array}$ & $20(40)$ & $12(24)$ & $p>0.05$ \\
\hline \multicolumn{5}{|c|}{${ }^{*}$ Chi-Square Test } \\
\hline
\end{tabular}

*Total numbers do not match, as patients had more than one complaint.

Pruritus, copious and offensive white discharge, and micturition complaints are seen more commonly in women with diabetic spouses. Pelvic pain is seen equally commonly in both groups.

\begin{tabular}{|c|c|c|c|}
\hline \multirow[t]{2}{*}{$\begin{array}{l}\text { Sl. } \\
\text { No. }\end{array}$} & \multirow{2}{*}{$\begin{array}{c}\text { Socio- } \\
\text { economic } \\
\text { Groups }\end{array}$} & \begin{tabular}{|c|}
$\begin{array}{c}\text { Women with Diabetic } \\
\text { Spouses Group }\end{array}$ \\
\end{tabular} & $\begin{array}{c}\text { Women in } \\
\text { Control Group }\end{array}$ \\
\hline & & n (\%) & n (\%) \\
\hline 1 & $\begin{array}{l}\text { Low } \\
\text { Socioeconomic } \\
\text { Groups }\end{array}$ & $4(8)$ & $19(38)$ \\
\hline 2 & $\begin{array}{c}\text { Middle } \\
\text { Income Group }\end{array}$ & $15(30)$ & $21(42)$ \\
\hline \multirow[t]{2}{*}{3} & $\begin{array}{l}\text { High Income } \\
\text { Group }\end{array}$ & $31(62)$ & $10(20)$ \\
\hline & Total & $50(100)$ & $50(100)$ \\
\hline \multicolumn{4}{|c|}{ Chi-square $=21.54 ; \mathrm{df}=2 ; \mathrm{p}<0.001$} \\
\hline \multicolumn{4}{|c|}{$\begin{array}{l}\text { Table 3. Distribution of Women } \\
\text { according to their Socioeconomic Status }\end{array}$} \\
\hline
\end{tabular}

More women (62\%) in spousal diabetes mellitus group belonged to high income group compared to $20 \%$ in control group. More women (38\%) in control group belonged to low socioeconomic groups compared to $8 \%$ in spousal diabetes mellitus group. This difference is statistically highly significant. Lack of health awareness; poor personal, menstrual and perineal hygiene may be one cause. Malnutrition and anaemia may also contribute to disease and debility due to low immunity.

\begin{tabular}{|c|c|c|c|c|}
\hline \multirow{2}{*}{$\begin{array}{c}\text { Sl. } \\
\text { No. }\end{array}$} & $\begin{array}{c}\text { Pap Smear } \\
\text { Report (Bethesda } \\
\text { System) }\end{array}$ & $\begin{array}{c}\text { Women with } \\
\text { Diabetic } \\
\text { Spouses Group }\end{array}$ & $\begin{array}{c}\text { Women in } \\
\text { Control } \\
\text { Group }\end{array}$ & \multirow{2}{*}{$\begin{array}{c}\text { P } \\
\text { value* }\end{array}$} \\
\cline { 3 - 4 } 1 & Mild Inflammatory & $11(22)$ & $12(24)$ & $\mathrm{p}>0.05$ \\
\hline 2 & $\begin{array}{c}\text { Moderate-to- } \\
\text { Severely } \\
\text { Inflammatory }\end{array}$ & $13(26)$ & $4(8)$ & $\mathrm{p}<0.05$ \\
\hline 3 & Mild Dysplasia & $2(4)$ & $1(2)$ & $\mathrm{p}>0.05$ \\
\hline 4 & $\begin{array}{c}\text { Severe Dysplasia/ } \\
\text { Malignant Cells }\end{array}$ & Nil (0) & Nil (0) & NA \\
\hline
\end{tabular}




\begin{tabular}{|c|c|c|c|c|}
\hline 5 & Normal Smear & $24(48)$ & $33(66)$ & $\mathrm{p}>0.05$ \\
\hline & Total & $50(100)$ & $50(100)$ & \\
\hline \multicolumn{5}{|c|}{ * Chi-square Test } \\
\hline \multicolumn{5}{|c|}{$\begin{array}{c}\text { Table 4. Association between Pap Smear Reports and Spousal } \\
\text { Diabetes among Women with Clinical Vulvovaginitis }\end{array}$} \\
\hline
\end{tabular}

Moderate-to-severely inflammatory smears were noticed more commonly in women with diabetic spouses $(26 \%)$ compared to the control group (8\%), which was statistically significant $(\mathrm{p}<0.05)$. Malignant cells were nil in both the groups. Diabetic spouse may be a predisposing factor for vulvovaginal disease in women as per this study.

\begin{tabular}{|c|c|c|}
\hline $\begin{array}{c}\text { Relief of } \\
\text { Symptoms }\end{array}$ & $\begin{array}{c}\text { Women with Diabetic } \\
\text { Spouses Group }\end{array}$ & $\begin{array}{c}\text { Women in } \\
\text { Control Group }\end{array}$ \\
\cline { 2 - 3 } & $\mathbf{n}(\%)$ & $\mathbf{n}(\%)$ \\
\hline$<1$ week & $11(22)$ & $15(30)$ \\
\hline$<2$ weeks & $24(48)$ & $31(62)$ \\
\hline$<3$ Weeks & $15(30)$ & $4(8)$ \\
\hline Total & $\mathbf{5 0}(100)$ & $\mathbf{5 0}(100)$ \\
\hline \multicolumn{3}{|c|}{ Chi-square = 7.87; df= 2; p <0.05 } \\
\hline \multicolumn{2}{|c|}{$\begin{array}{r}\text { Table 5. Association between Relief of Symptoms } \\
\text { after Treatment and Spousal Diabetes among } \\
\text { Women with Clinical Vulvovaginitis }\end{array}$} \\
\hline
\end{tabular}

More than ninety percent of women in the control group, whose spouses were not diabetic became asymptomatic within 2 weeks. In comparison, almost $1 / 3^{\text {rd }}$ women with diabetic spouses took 3 weeks or more to recover and approximately 50\% recovered between $1-2$ weeks. This difference is statistically significant.

More severe symptoms, more inflammatory Pap smears and more time to recover is noticed in women with diabetic spouses.

\begin{tabular}{|c|c|c|}
\hline $\begin{array}{c}\text { Recurrence } \\
\text { of Symptoms }\end{array}$ & $\begin{array}{c}\text { Women with Diabetic } \\
\text { Spouses Group (\%) }\end{array}$ & $\begin{array}{c}\text { Women in Control } \\
\text { Group (\%) }\end{array}$ \\
\hline <6 Months & $9(18)$ & $3(6)$ \\
\hline 6-12 Months & $7(14)$ & $4(8)$ \\
\hline $12-18$ Months & $13(26)$ & $7(14)$ \\
\hline $18-24$ Months & $6(12)$ & $4(8)$ \\
\hline No recurrence & $15(30)$ & $32(64)$ \\
\hline Total & $\mathbf{5 0 ( 1 0 0 )}$ & $\mathbf{5 0}(100)$ \\
\hline \multicolumn{3}{|c|}{ Chi-square=12.167; df= 4; p < 0.05 } \\
\hline $\begin{array}{c}\text { Table 6. Association between Recurrence After Treatment } \\
\text { and Spousal Diabetes among Women with Clinical } \\
\text { Vulvovaginitis }\end{array}$ \\
\hline
\end{tabular}

Two-thirds of women with non-diabetic spouses recovered completely and there was no recurrence in the 2year followup. In contrast, $2 / 3$ rds of women with diabetic spouses showed recurrence of symptoms during the same period. This difference is statistically significant.

\section{DISCUSSION}

Diabetes in men with and without glycaemic control, predisposes them to genital and urinary tract infections. They in turn may transmit the infection to their wives, which are persistent and recurrent despite treatment.

In this study, it is clearly evident that women with diabetic spouses are more prone for vulvovaginal infections. As it is, diabetic women are more predisposed to vulvovaginal infections than others. ${ }^{1}$ As seen in this study, non-diabetic women with diabetic spouses suffer genital infections more severely than those with non-diabetic spouses.
Vulvovaginitis in women has multiple causes. ${ }^{5}$ Spousal diabetes is found to be another associated factor, which may be aetiological cause as seen in this study, though the sample size may be small.

Women patients with diabetes mellitus are at increased risk of vulvovaginal candidiasis. ${ }^{6-8}$ Incidence of vaginal infections are more in diabetic women. ${ }^{9}$ In the present study, women with diabetic spouse have increased frequency of vulvovaginal infections with prolonged durations and persistence of the disease. Symptomatic relief takes a longer time compared to their counterparts with non-diabetic husbands.

Recurrence rate is $64 \%$ in women with diabetic husbands and they have multiple symptoms and complaints compared to the control group.

Pap smear showed more frequent moderate-to-severe inflammatory response in the study group, though there was no malignancy or pre-malignancy in both groups.

\section{To Conclude}

Diabetes mellitus in men predisposes their partners to more severe vulvovaginal infections with multiple symptoms, high recurrence rate and prolonged suffering. Spousal Diabetes, therefore can be taken as important aetiological factor for vulvovaginal infections in their partners.

\section{CONCLUSION}

Women with spouses suffering from diabetes mellitus have more incidence of moderate-to-severe vulvovaginal infections. Their symptoms are more severe and recurrence rate is higher in comparison to women whose spouses are not diabetic. No cases of cervical malignancy are seen, but cervical smears showed higher incidence of moderate-tosevere inflammatory smears.

\section{REFERENCES}

[1] Howkins and Bourne. Specific vaginal infections. Shaw's text book of Gynaecology. 16 th edn. India: Elsevier Health Sciences 2015: p. 383.

[2] Healthline. Diabetes and yeast infections: Is there a link? 2016 https://www.healthline.com/health/diabetes/diabete s-and-yeast-infections\#overview1.

[3] VG Vaginal Health Organization. Vaginal Yeast infections - a complete guide to diagnosis, treatment and prevention. 2010.

[4] R Core Team. R: a language and environment for statistical computing. R Foundation for Statistical Computing, Vienna, Austria, 2013. URL https://www.R-project.org/.

[5] Wikipedia. Vaginitis. 2017. https://www.revolvy.com/topic/Vulvovaginitis\&item type=topic.

[6] Trichomonasis. Contemperory women's issues. Healthy Women, Gale 2010.

[7] National Institutes of Health. Vaginal yeast infection. MedlinePlus.

https://medlineplus.gov/ency/article/001511.htm

[8] Wexler A. Diabetes and yeast infections: What you need to know. 2017.

https://www.medicalnewstoday.com/articles/31782 4.php.

[9] Sharma M, Solanki A. Prevalence of Candida in pregnant women with and without diabetes. Int J Curr Microbiol App Sci 2014;3(4):605-10. 